\section{Daylength, Light Quality, and Temperature Influence Growth and Development of Achimenes}

\author{
J.C. Vlahos ${ }^{1}$, G.F.P. Martakis ${ }^{2}$, and E. Heuvelink ${ }^{3}$ \\ Department of Horticulture, Agricultural University, P. O. Box 30, 6700 \\ AA Wageningen, The Netherlands
}

\begin{abstract}
Additional index words. daylength extension, incandescent light, fluorescent light, growth analysis
\end{abstract}

\begin{abstract}
The effects of supplementary irradiance $\left(20 \mu \mathrm{mol} \cdot \mathrm{s}^{-1} \cdot \mathrm{m}^{-2}\right.$ for 6 hours $)$ with incandescent light (I) or fluorescent compact gas-discharge lamps (CF) vs. a basic irradiance $\left(96 \mu \mathrm{mol} \cdot \mathrm{s}^{-1} \cdot \mathrm{m}^{-2}\right.$ for $\left.12 \mathrm{~h}\right)$ with fluorescent $(\mathrm{F})$ light at 17 or $25 \mathrm{C}$ was studied for Achimenes hybrids 'Flamenco', 'Hilda', and 'Rosenelfe'. The additional I increased leaf area (LA) and plant dry weight (DW) in 'Hilda' and 'Rosenelfe' and promoted stem elongation in all three cultivars. Additional $F$ had no effect on DW. However, depending on cultivar, responses for LA varied. An increase in the number of flowers was promoted only in 'Rosenelfe' by I and CF compared with the control. In all cultivars, the supplementary CF, when compared with the I, reduced LA and DW. LA was significantly larger and DW higher at higher temperature, except for 'Rosenelfe', where DW was not influenced and LA was smaller at the higher temperature. All three cultivars produced a longer stem and more flowers at the higher temperature. Calculated growth responses were influenced by an interaction between temperature and cultivar.
\end{abstract}

Hybrids of the genus Achimenes, Gesneriaceae, are cultivated as potted plants in the United States and Europe. Achimenes will flower regardless of daylength after development of the third or fourth leaf whorl (Zimmer and Junker, 1985). Best vegetative and generative growth is achieved at 20C and $16 \mathrm{~h}$ light (Rohde, 1974). Recently, the influence of light and temperature on growth and development of several Achimenes cultivars was quantified. Higher temperatures ( 21 or $25 \mathrm{C}$ vs. $17 \mathrm{C}$ ) increased the number of leaf whorls and favored flowering; however, responses varied among cultivars (Vlahos, 1990a). Extending natural daylength with high-pressure sodium lamps increased growth and flowering (Vlahos, 1989, 1990b). Low light intensities combined with long days (at the same daily light integral) increased growth and flowering in three cultivars of Achimenes due to an increase in relative growth rate (RGR) and net assimilation rate (NAR), which was attributed to more efficient light use at lower light intensity (Vlahos et al., 1991).

Apart from light intensity and light integral, it is well known that light quality influences plant growth and morphogenesis

\footnotetext{
Received for publication 1 Apr. 1992. Accepted for publication 21 May 1992. Publication no. 567, Dept. of Horticulture, Agricultural Univ. Wageningen, The Netherlands. The cost of publishing this paper was defrayed in part by the payment of page charges. Under postal regulations, this paper therefore must be hereby marked advertisement solely to indicate this fact.

${ }^{1}$ Professor of Botany. Current address: Dept. of Horticulture, Technological Educational Institute (T.E.I.), Iraklio, 71500 Crete, Greece.

'Statistician.

${ }^{3}$ Assistant Professor.
}

(Healy et al., 1980; Smith, 1982). Most research on light quality refers to the effects of different light sources combined with different irradiance levels or photoperiods on growth and development. Incandescent light increases stem height, reducing plant quality in several pot plants. The fluorescent lamp, although it does not increase stem height as much as incandescent light, is not commonly used in commercial plant production (Andersen, 1986; Kristiansen, 1988). Red light promoted whereas far-red light suppressed rhizome formation in leaf or stem cuttings of Achimenes 'Major' (Deutch, 1974). We found no reports of other effects of light quality in Achimenes. The present experiment was designed to investigate the effect of supplementary light quality on growth and development in three Achimenes cultivars at two temperatures.

Design of experiment. 'Flamenco', 'Hilda Michelssen' ('Hilda'), and 'Rosenelfe' were obtained from a commercial grower in Mar. 1985 and grown in 10-cm (0.3-liter) plastic pots in a commercial potting medium $(\mathrm{pH}$ 5.5-5.8) consisting of 6 peat mold : 4 rough peat $(\mathrm{v} / \mathrm{v})$. Plants were grown for 10 days in a greenhouse at $21 / 18 \mathrm{C}$ (day/night) under natural daylength to establish the plants.

On 3 Apr. 198.5, the plants were placed in six growth chambers (Controlled Environments Ltd., Winnipeg, Manitoba, Canada) (length $\times$ width $\times$ height $=185 \times 77 \times$ $137 \mathrm{~cm}$ ) and grown for 9 weeks at 17 or $25 \mathrm{C}$ (constant day/night), each combined with three light regimes. At the start of the experiment, plants had an average height of 4 $\mathrm{cm}$ with three to four leaf whorls (nodes) with no flower buds visible, and with only axillary shoots emerging from the lower leaf axils. The light regime treatments were F:
$12 \mathrm{~h}$ irradiance provided from fluorescent Philips TL33 tubes $\left[96 \mu \mathrm{mol} \cdot \mathrm{s}^{-1} \cdot \mathrm{m}^{-2}\right.$ photosynthetic active radiation (PAR); high $\mathrm{R}$ : FR ratio]; I: $12 \mathrm{~h}$ irradiance (same as F), extended for $6 \mathrm{~h}$ with incandescent Philips GLS lamps $\left(20 \mu \mathrm{mol} \cdot \mathrm{s}^{-1} \cdot \mathrm{m}^{-2} \mathrm{PAR}\right.$; low R : FR ratio); CF: $12 \mathrm{~h}$ irradiance (same as F) extended for $6 \mathrm{~h}$ with Philips SL compact gas-discharge lamps $\left(20 \mu \mathrm{mol} \cdot \mathrm{s}^{-1} \cdot \mathrm{m}^{-2} \mathrm{PAR}\right.$; high $\mathrm{R}$ : FR ratio). PAR encompassed 400 to $700 \mathrm{~nm}\left(\mu \mathrm{mol} \cdot \mathrm{s}^{-1} \cdot \mathrm{m}^{-2}\right)$. The CF lamp (miniature fluorescent) has the same spectral emission as the $\mathrm{F}$, but is a more practical and energy-efficient lamp.

We used a split-plot design, where the six combinations of temperature and light regime were applied in the whole plots (growth chambers), with cultivars as subplots (16 plants per cultivar in each growth chamber). The combinations of temperature and light regime were not replicated. The experiment involved a total of 288 plants.

Leaf area (LI-COR model 3100 area meter; LI-COR, Lincoln, Neb.) and leaf, stem, root, and rhizome fresh and dry weights $(60 \mathrm{C}$, forced-air oven for at least 5 days) were determined on four plants for each cultivar at $0,21,42$, and 63 days after the start of the experiment. At the final harvest, plant height, number of leaf whorls, and number of axillary shoots were also measured. The number of days to first flower anthesis was recorded by daily observations. Data were subjected to an analysis of variance with least significant difference (LSD) mean separation.

Growth analysis. Growth analysis was conducted according to the functional approach (Hunt, 1982). The best-fitting polynomial (up to the sixth degree) relating the natural logarithms of plant dry weight (DW), leaf dry weight (DW), and leaf area (LA) with time was calculated (Nilwik, 1981). The degree of the polynomials was chosen by using the "stepwise" F test $(P<0.001)$ described by Draper and Smith (1981). In most cases a quadratic function provided the most satisfactory fit to the data. Therefore, a quadratic relationship was fitted to all the plots of the natural logarithms of DW, DW, and LA against time.

Since growth rate is size dependent (ontogenetic effect), it is necessary to take this into account. Terry (1968) used DW as an index of ontogenetic state. This approach has also been applied here. Therefore, mean values of RGR (per day), NAR (milligrams per square centimeter per day), leaf area ratio (LAR; LA/DW; square centimeters/milligram), specific leaf area (SLA; LA/DW; square centimeters/milligram), and leaf weight ratio (LWR; DW/DW) were compared on the basis of a DW interval instead of a time interval. This DW interval was $107-508 \mathrm{mg}$ (InDW $=4.68-6.23)$, where the lower limit equals the maximum fitted DW at the first harvest and the upper limit equals the minimum fitted DW at the last harvest. Thus, no extrapolation of the measured data is required.

Instantaneous values for RGR, NAR, LAR, SLA, and LWR were calculated by means of the described polynomials, relating DW, 
Table 1. Effect of light regime and cultivar on plant height, number of flowers, leaf area, and total dry weight of Achimenes.

\begin{tabular}{|c|c|c|c|c|c|c|c|c|c|c|c|c|c|c|c|}
\hline \multirow[b]{3}{*}{ Cultivar } & \multicolumn{3}{|c|}{ Plant ht $(\mathrm{cm})$} & \multicolumn{3}{|c|}{ No. flowers } & \multirow{2}{*}{\multicolumn{3}{|c|}{$\frac{\text { No. axillary shoots }}{\text { Light regime }}$}} & \multicolumn{3}{|c|}{ Leaf area $\left(\mathrm{cm}^{2}\right)$} & \multicolumn{3}{|c|}{ Total dry wt (mg) } \\
\hline & \multirow[b]{2}{*}{$\mathrm{F}$} & \multirow[b]{2}{*}{ I } & \multirow[b]{2}{*}{$\mathrm{CF}$} & \multirow[b]{2}{*}{$\mathrm{F}$} & \multirow[b]{2}{*}{3} & \multirow[b]{2}{*}{ CF } & & & & & & & & & \\
\hline & & & & & & & $\mathrm{F}$ & I & $\mathrm{CF}$ & $\mathrm{F}$ & I & $\mathrm{CF}$ & $\mathrm{F}$ & I & CF \\
\hline Flamenco & $9.8^{2}$ & 18.7 & 11.5 & 7.2 & 8.8 & 9.9 & 1.7 & 1.3 & 1.9 & 154 & 120 & 86 & 1068 & 119 & 1088 \\
\hline Hilda & 10.2 & 16.5 & 12.5 & 7.1 & 7.9 & 8.8 & 1.1 & 1.4 & 0.9 & 173 & 256 & 220 & 938 & 1658 & 1255 \\
\hline Rosenelfe & 20.0 & 28.5 & 23.9 & 17.8 & 28.4 & 35.4 & 5.8 & 4.3 & 5.5 & 325 & 342 & 274 & 1765 & 2183 & 1971 \\
\hline LSD at $P=0.05$ & & 6.9 & & & 12.0 & & & 1.0 & & & 30.1 & & & 371 & \\
\hline
\end{tabular}

${ }^{2}$ Values are means of two temperature regimes and 16 plants per cultivar.

Table 2. Effect of temperature and cultivar on plant height, number of flowers, leaf area, and total dry weight of Achimenes.

\begin{tabular}{|c|c|c|c|c|c|c|c|c|c|c|}
\hline \multirow[b]{3}{*}{ Cultivar } & \multicolumn{2}{|c|}{ Plant ht $(\mathrm{cm})$} & \multicolumn{2}{|c|}{ No. flowers } & \multirow{2}{*}{\multicolumn{2}{|c|}{$\frac{\text { No. leaf whorls }}{\text { Temp }\left({ }^{\circ} \mathrm{C}\right)}$}} & \multicolumn{4}{|c|}{ Leaf area $\left(\mathrm{cm}^{2}\right)$ Total dry wt $(\mathrm{mg})$} \\
\hline & \multirow[b]{2}{*}{17} & \multirow[b]{2}{*}{25} & \multirow[b]{2}{*}{17} & \multirow[b]{2}{*}{25} & & & \multirow[b]{2}{*}{17} & \multirow[b]{2}{*}{25} & \multirow[b]{2}{*}{17} & \multirow[b]{2}{*}{25} \\
\hline & & & & & \multicolumn{2}{|c|}{ lemp (C) } & & & & \\
\hline Flamenco & $11.2^{2}$ & 15.5 & 6.6 & 10.7 & 7.7 & 9.5 & 91 & 149 & 920 & 1310 \\
\hline Hilda & 9.5 & 16.7 & 3.6 & 12.4 & 7.8 & 10.6 & 166 & 267 & 902 & 1665 \\
\hline Rosenelfe & 20.3 & 28.0 & 12.8 & 41.6 & 10.0 & 13.3 & 334 & 294 & 1818 & 2068 \\
\hline LSD at $P=0.05$ & \multicolumn{2}{|c|}{2.8} & \multicolumn{2}{|c|}{9.8} & \multicolumn{2}{|c|}{0.8} & \multicolumn{2}{|c|}{24.6} & \multicolumn{2}{|c|}{303.4} \\
\hline
\end{tabular}

${ }^{2}$ Values are means of three light regimes and 16 plants per cultivar.

Table 3. Effect of temperature and cultivar on mean values of RGR, NAR, LAR, SLA, and LWR over the DW interval $107-508 \mathrm{mg} .^{x, y}$

\begin{tabular}{|c|c|c|c|c|c|c|c|c|c|c|}
\hline \multirow[b]{3}{*}{ Cultivar } & \multicolumn{2}{|c|}{ RGR/day } & \multicolumn{2}{|c|}{$\begin{array}{c}\text { NAR } \\
\left(\mathrm{mg} \cdot \mathrm{cm}^{-2} \cdot \text { day }^{-1}\right)\end{array}$} & \multirow{2}{*}{\multicolumn{2}{|c|}{$\frac{\begin{array}{c}\text { LAR } \\
\left(\mathrm{cm}^{-2} \cdot \mathrm{mg}^{-1}\right)\end{array}}{\text { Temp }\left({ }^{\circ} \mathrm{C}\right)}$}} & \multicolumn{2}{|c|}{$\begin{array}{c}\text { SLA } \\
\left(\mathrm{cm}^{-2} \cdot \mathrm{mg}^{-1}\right)\end{array}$} & \multicolumn{2}{|c|}{ LWR } \\
\hline & \multirow[b]{2}{*}{17} & \multirow[b]{2}{*}{25} & \multirow[b]{2}{*}{17} & \multirow[b]{2}{*}{25} & & & \multirow[b]{2}{*}{17} & \multirow[b]{2}{*}{25} & \multirow[b]{2}{*}{17} & \multirow[b]{2}{*}{25} \\
\hline & & & & & \multicolumn{2}{|c|}{$\begin{array}{ll}17 & 25\end{array}$} & & & & \\
\hline Flamenco & $0.0633^{2}$ & 0.0653 & 0.532 & 0.449 & 0.121 & 0.166 & 0.228 & 0.288 & 0.529 & 0.571 \\
\hline Hilda & 0.0406 & 0.0622 & 0.228 & 0.345 & 0.182 & 0.183 & 0.269 & 0.286 & 0.677 & 0.644 \\
\hline Rosenelfe & 0.0651 & 0.0728 & 0.338 & 0.463 & 0.223 & 0.167 & 0.365 & 0.314 & 0.611 & 0.530 \\
\hline LSD at $P=0.05$ & 50.0 & 017 & 0 . & 14 & 0.0 & & 0. & & & 83 \\
\hline
\end{tabular}

${ }^{2} \mathrm{RGR}$, relative growth rate; NAR, net assimilation rate; LAR, leaf area ratio; SLA, specific leaf area; LWR, leaf weight ratio; DW, dry weight.

${ }^{y}$ Values are means of three light regimes and 16 plants per cultivar.

$\mathrm{DW}_{1}$, and LA with time. Average RGR, NAR, LAR, SLA, and LWR values were calculated by taking the mean of daily instantaneous values over the DW interval. Results were statistically analyzed with analysis of variance followed by an LSD test.

Light regime. The design did not provide for a test of an interaction between light regime and temperature. Significant interactions between light regime and cultivar were found for plant height, number of flowers, leaf area, and total dry weight (Table 1). Additional lighting for $6 \mathrm{~h}$ with I lamps increased plant height in all three cultivars; however, this effect was significant only in 'Flamenco' and 'Rosenelfe'. The number of leaf whorls was unaffected (data not shown), which means that increased plant height was a result of elongation (longer internodes). This elongation reduces plant quality. Low $\mathrm{R}$ : FR ratio (incandescent light), compared with high $\mathrm{R}$ : FR ratio (fluorescent light), is known to promote stem elongation in a wide range of ornamental plants (Cathey and Campbell, 1975; Smith, 1986). Additional CF light (high $\mathrm{R}$ : FR ratio) had no significant effect on plant height (Table 1). Kristiansen (1988) reported similar results for Campanula. Incandescent light is known to retard or inhibit lateral branching in several plants (Cathey and Campbell, 1975; Grimstad, 1987). In the present investigation, only 'Rosenelfe' responded with reduced branching, ex- pressed as number of axillary shoots, to the low R : FR ratio of incandescent (I) light (Table 1). Wilkins (1985) and Grimstad (1987) reported for Fushsia and Gloxinia that flower development was not influenced by light source or photoperiod. Results in 'Flamenco' and 'Hilda' are similar to these findings, as the total number of flowers was not significantly affected by the light regime. In 'Rosenelfe', however, supplementary lighting with $\mathrm{CF}$ increased the number of flowers compared with FL light regime (Table 1).

Flower development in several day-neutral plants is strongly influenced by the light integral (Kinet and Sachs, 1984). In 'Rosenelfe' the increased light integral (by 10\%) may have promoted flowering, since daylength extension with I had a positive effect on the number of flowers. The number of days to first flower anthesis was not significantly affected by light regime (data not shown) for any of the cultivars studied.

Lighting by either I or CF reduced LA in 'Flamenco' and increased it in 'Hilda' (Table 1). In 'Rosenelfe' LA was reduced only by CF. Additional I light significantly increased LA in all cultivars when compared with CF. In 'Hilda' and 'Rosenelfe' DW was increased by additional incandescent light (I) compared to the other light regimes, whereas 'Flamenco' was not affected. Dry weight in several species increases when incandescent irradiance supplements fluorescent irradi- ance (Dijak and Ormrod, 1985; Knight and Mitchell, 1988). Our results for 'Hilda' and 'Rosenelfe' agree with these findings. Mortensen and Stromme (1987) reported that blue light, containing a high $\mathrm{R}$ : FR ratio [R : FR ratio $=$ ratio of number of photons in the $655-665 \mathrm{~nm}$ band (red) to that in the 725$735 \mathrm{~nm}$ band (far red) (Bjorn, 1986)], reduced dry weight and leaf area in several plant species. Results for 'Hilda' agree with the above findings, since under both $\mathrm{F}$ and CF light (high R : FR ratio) LA and DW decreased compared with that associated with I. The other cultivars varied in their response. The R : FR ratio of the three lamp types used in this experiment was not measured, but according to Hart (1988), this ratio might be as much as 20 times higher in fluorescent light then in incandescent light. Considering that equal PAR $(400-700 \mathrm{~nm})$ was maintained in I and CF light regimes, the differences observed are due to light quality.

Deutch (1974) found that far red light suppressed and red light promoted rhizome formation in leaf cuttings in Achimenes 'Major', yet light regimes had no significant effect on the number of rhizomes formed by plants in this study (data not shown).

Temperature. Significant interactions between temperature and cultivar existed for plant height, number of leaf whorls, number of flowers, LA, and DW (Table 2). Higher temperature stimulated plant height and increased number of leaf whorls in all cultivars. Time to first flower anthesis was shortened in 'Rosenelfe' and 'Hilda' (data not shown). At $25 \mathrm{C}$, the number of flowers was higher than at $17 \mathrm{C}$ in 'Rosenelfe'. Higher temperature is known to promote growth and flowering in many species (Djurhuus, 1985; Gertsson, 1984; Kristiansen, 1988). 'Rosenelfe' produced more flowers than the other two cultivars, since each leaf axil was capable of developing three to nine flowers (Vlahos, 1990a).

Both 'Flamenco' and 'Hilda' showed a significantly higher LA and DW at 25 than at $17 \mathrm{C}$. However, for 'Rosenelfe', LA was smaller at $25 \mathrm{C}$, yet DW was not significantly affected by temperature in this cultivar (Table 2). Dry weight of rhizomes was not significantly affected by temperature in any of the three cultivars (data not shown). 'Hilda' developed no rhizomes until the end of the experiment.

Growth analysis. No significant interaction between light regime and cultivar was found for any of the calculated growth characteristics. However, supplementary lighting 
provided with I or CF $\left(20 \mu \mathrm{mol} \cdot \mathrm{s}^{-1} \cdot \mathrm{m}^{-2}\right)$ for $6 \mathrm{~h} \cdot$ day $^{-1}$ appeared to be high enough to give higher values for NAR $(27 \%$ and $43 \%$, respectively) than the basic irradiance (data not shown). This result is as expected, because Achimenes is a "shade plant" (van Raalte, 1969) and, therefore, is adapted to use low light intensity. Significant interactions $(P<0.05)$ between temperature and cultivar were found for RGR and LWR (Table 3 ). Differences between cultivars were greater at $17 \mathrm{C}$, than at $25 \mathrm{C}$. RGR was lowest for 'Hilda' and increased 53\% with temperature; for 'Flamenco' and 'Rosenelfe' this increase with temperature was smaller (3\% and $12 \%$, respectively). LWR for 'Hilda' and 'Rosenelfe' was lower (5\% and 13\%) at 25C than at $17 \mathrm{C}$, whereas in 'Flamenco' it increased with temperature $(8 \%)$.

The low RGR for 'Hilda' was the result of the lowest value for NAR, compared with that of the other two cultivars, combined with an intermediate value for LAR, whereas the high RGR for 'Rosenelfe' resulted from the highest LAR and intermediate NAR (Table $3)$. Therefore, NAR, the photosynthetic component of growth, and LAR, the morphological component, both appeared to be important factors in determining the differences in growth among the cultivars.

Our results indicate that, depending on cultivar, a 6-h daylength extension, providing as little light energy as $20 \mu \mathrm{mol} \cdot \mathrm{s}^{-1} \cdot \mathrm{m}^{-2}$ from either fluorescent or incandescent lamps, affects growth and development in Achimenes. However, the CF lamp is to be preferred as it does not cause stem elongation.

\section{Literature Cited}

Andersen, A. 1986. Comparison of fluorescent lamps as an energy source for production of tomato plants in a controlled environment. Scientia Hort. 28:1-18.
Bjorn, L.O. 1986. Introduction, p. 1-14. In: R.E. Kendrick and G.H.M. Kronenberg (eds.). Photomorphogenesis in plants. Martinus Nijhoff, Dordrecht, The Netherlands.

Cathey, H.M. and L.E. Campbell. 1975. Effectiveness of five vision-lighting sources on photoregulation of 22 species of ornamental plants. J. Amer. Soc. Hort. Sci. 100:65-71.

Deutch, B. 1974. Bulblet formation in Achimenes longiflora. Physiol. Plant. 30:113-118.

Dijak, M. and D.P. Ormrod. 1985. Responses involved in increased dry matter production with supplementary incandescent radiation in growth chambers. Environ. Expt. Bot. 25:195-201.

Djurhuus, R. 1985. The effect of photoperiod and temperature on growth and development of $\mathrm{Be}$ gonia xtuberhybrida 'Karelsk jomfru'. Scientia Hort. 27:123-131.

Draper. N.R. and H. Smith. 1981. Applied regression analysis. Wiley, New York.

Gertsson, U.E. 1984. Effect of temperature, daylength and light intensity on growth and development of Dipladenia sanderi Hemsl. 'Rosea'. Scientia Hort. 22:287-293.

Grimstad, S.O. 1987. The effect of supplemental irradiation with different light sources on growth and flowering of Gloxinia (Sinningia speciosa (Ledd) Hiern.). Scientia Hort. 32:217-305.

Hart, J.W. 1988. Light and plant growth, Urwin Hyman, London. p. 41.

Healy, W.E., R.D. Heins, and H.F. Wilkins. 1980 Influence of photoperiod and light quality on lateral branching and flowering in selected vegetatively propagated plants. J. Amer. Soc. Hort. Sci. 109:812-816.

Hunt, R. 1982. Plant growth curves. The functional approach to plant growth analysis. Edward Arnold, London.

Kinet, J.M. and R.M. Sachs. 1984. Light and flower development, p. 211-225. In: D. VincePrue, B. Thomas, and E.K. Cockshull (eds.). Light and the flowering process. Academic, London.

Knight, S.L. and C.A. Mitchell. 1988. Effects incandescent radiation on photosynthesis, growth rate and yield of 'Weldmann's Green' leaf lettuce. Scientia Hort. 35:37-49.

Kristiansen, K. 1988. Light quality regulates flower initiation, differentiation and development in
Campanula carpatica Jacq. 'Karl Forster'. Scientia Hort. 35:275-283.

Mortensen, L.M. and E. Stromme. 1987. Effects of light quality on some greenhouse crops. Scientia Hort. 33:27-36.

Nilwik, H.J.M. 1981. Growth analysis of sweet pepper (Capsicum annum L.). The influence of irradiance and temperature under glasshouse conditions in winter. Ann. Bot. 48:129-136.

Rohde, J. 1974. Einfluss der Tageslänge und Temperatur auf die Trieb und Blütenbildung der Achimenes hybriden 'Valse bleu' und 'Dornröschen'. Gartenbauwissenschaft 39:135-150.

Smith, H. 1982. Light quality, photoperception and plant strategy. Annu. Rev. Plant Physiol. $33: 481-518$

Smith, H. 1986. The perception of light quality, p. 187-216. In: R.E. Kendrick and G.H.M Kronenberg (eds.). Photomorphogenesis in plants. Martinus Nijhoff, Dordrecht, The Netherlands.

Terry, N. 1968. Developmental physiology of sugar beet. I. The influence of light and temperature on growth. J. Expt. Bot. 19:795-811.

van Raalte, D. 1969. Het Handboek voor de Bloemisterij. Deel IV-De belangrijkste Potplanten. Born periodiken N.V. Amsterdam. p. 75.

Vlahos, J.C. 1989. Effects of GA, BA and NAA on dry matter partitioning and rhizome development on two cultivars of Achimenes longiflora DC. under three levels of irradiance. Acta Hort. 251:79-92.

Vlahos, J.C. 1990a. Temperature and irradiance influence growth and development of three cultivars of Achimenes. HortScience 25:1597-1598.

Vlahos, J.C. 1990b. Daylength influences growth and development of Achimenes cultivars. HortScience 25:1595-1596.

Vlahos, J.C., E. Heuvelink, and G.F.P. Martakis. 1991. A growth analysis study on 3 Achimenes cultivars grown under 3 light regimes. Scientia Hort. 46:275-282.

Wilkins, H.F. 1985. Fuchsia $\times$ hybrida, p. 3841. In: A.H. Halevy (ed.). Handbook of flowering. vol. 3. CRC Press, Boca Raton, Fla.

Zimmer, K. and K. Junker. 1985. Achimenes, p. 391-392. In: A.H. Halevy (ed.). Handbook of flowering. vol. 1. CRC Press, Boca Raton, Fla. 